\title{
Hubungan Personal Hygiene Dengan Kejadian Skabies Di Pondok Pendidikan Islam Darul Ulum, Palarik Air Pacah, Kecamatan Koto Tangah Padang Tahun 2013
}

\author{
Suci Chairiya Akmal, Rima Semiarty, Gayatri
}

\begin{abstract}
Abstrak
Pada tahun 2010, penyakit kulit infeksi termasuk 10 penyakit terbanyak di Sumatera Barat dengan 106.568 kasus. Di kota Padang, penyakit kulit infeksi merupakan penyakit nomor dua ternyak dengan 24.058 kasus baru dan 13.148 kasus lama. Kasus infeksi kulit banyak ditemukan di daerah Air Dingin dengan 1781 kasus pada tahun 2010. Skabies merupakan infeksi parasit pada kulit yang disebabkan oleh Sarcoptes Scabei var Hominis. Personal hygiene diduga berperan terhadap skabies. Penelitian ini bertujuan untuk mengetahui hubungan personal hygiene dengan kejadian skabies di Pondok Pendidikan Islam Darul Ulum, Palarik, Air Pacah, Padang. Desain penelitian ini adalah analitik cross sectional dengan menggunakan kuisioner dan wawancara observasional. Populasi dalam penelitian ini adalah seluruh santri yang bersedia menjadi responden dan hadir pada saat penelitian yaitu 138 orang. Analisis statistik yang dgunakan adalah Chi-Square. Hasil penelitian menunjukkan bahwa prevalensi skabies di Pondok Pendidikan Islam Darul Ulum, Palarik, Air Pacah, Padang adalah 34 orang (24,6\%) dari 138 orang. Berdasarkan hasil uji statistik menunjukkan bahwa kejadian skabies mempunyai hubungan dengan personal hygiene $(P=0,00)$. Disarankan untuk dilakukan penyuluhan yang bekerja sama dengan dokter puskesmas tentang bagaimana cara pola hidup bersih dan sehat dan menerapkannya dalam kehidupan sehari-hari.
\end{abstract}

Kata kunci: Personal hygiene, Skabies

\begin{abstract}
Arial 9 italic In 2010, infectious skin diseases including 10 most diseases in West Sumatra with 106.568 incident cases. Infectious skin disease in the city of Padang is the second disease ever, that 24.058 new cases and 13.148 old cases. Cases of scabies in the city of Padang is found in Air Dingin with the number 1781 cases in 2010. Scabies is a parasitic infection of the skin caused by Sarcoptes Scabei var Hominis. Personal hygiene is suspected to contribute to the incidence of scabies. This study aimed to determine the relationship of personal hygiene with the incidence of scabies in students at boarding Darul Ulum Islamic Education, Palarik, Air Pacah, Padang. Design research is an analytic cross sectional observational study using questionnaires and interviews. The population in this study were all students who are willing to respondents and was present at the time of the study that is 138 peoples. Statistical analysis using Chi-Square. The results showed that the prevalence of scabies in boarding Darul Ulum Islamic Education, Palarik, Air Pacah is 34 peoples (24,6\%) from 138 peoples. Based on the results of the statistical Chi-Square test showed that the incidence of scabies is related to personal hygiene $(P=0,00)$. It is advisable to do outreach work with doctors clinic on how to clean and healthy lifestyle, and apply them in everyday life.
\end{abstract}

Keywords: Personal hygiene, Scabies

Affiliasi penulis : Suci Chairiya Akmal,

Korespondensi : Fakultas Kedokteran Universitas Andalas, email : suciakmal@yahoo.com, Telp: 0751-31746

\section{Pendahuluan}

Pemeliharaan personal hygiene sangat menentukan status kesehatan, dimana individu secara sadar dan atas inisiatif pribadi menjaga kesehatan dan mencegah terjadinya penyakit. Upaya kebersihan diri ini mencakup tentang kebersihan rambut, mata, telinga, gigi, mulut, kulit, kuku, serta kebersihan dalam berpakaian.

Salah satu upaya personal hygiene adalah merawat kebersihan kulit karena kulit berfungsi untuk melindungi permukaan tubuh, memelihara suhu tubuh dan mengeluarkan kotoran-kotoran tertentu. Mengingat kulit penting sebagai pelindung organorgan tubuh, maka kulit perlu dijaga kesehatannya. Penyakit kulit dapat disebabkan oleh jamur, virus, kuman, parasit. Salah satu penyakit kulit yang disebabkan oleh parasit adalah Skabies. ${ }^{2}$

Skabies merupakan infeksi parasit pada kulit yang disebabkan oleh Sarcoptes scabei var hominis. ${ }^{3}$ Insiden skabies di negara berkembang menunjukkan siklus fluktuasi. ${ }^{4}$ Distribusi, prevalensi, dan insiden penyakit infeksi parasit pada kulit ini tergantung dari area dan populasi yang diteliti. Penelitian di suatu kota miskin di Bangladesh menunjukkan bahwa semua anak usia kecil dari 6 tahun menderita skabies, serta di pengungsian Sierra Leone ditemukan $86 \%$ anak pada usia 5-9 tahun terinfeksi Sarcoptes scabei. ${ }^{5}$ Indonesia mempunyai prevalensi skabies yang cukup tinggi dan cenderung tinggi pada anak-anak sampai dewasa. $^{6}$ Pada tahun 2010, penyakit kulit infeksi termasuk 10 penyakit terbanyak di Sumatera Barat dengan kejadian 106.568 kasus. ${ }^{7}$ Penyakit kulit infeksi di Kota Padang merupakan penyakit kedua terbanyak, yaitu 24.058 kasus baru dan 13.148 kasus lama. Kasus skabies di kota Padang banyak ditemukan di daerah Air Dingin dengan jumlah 1.781 kasus pada tahun 2010. Kejadian skabies pada umumnya terjadi peningkatan setiap bulan. Pada bulan Oktober 2010 kasus skabies berjumlah 142 kasus, 157 kasus pada bulan November 2010, dan mengalami sedikit penurunan pada bulan Desember 2010, yaitu 129 kasus. $^{8}$

Siswa pondok pesantren merupakan subjek penting dalam permasalahan skabies. Karena dari data-data yang ada sebagian besar yang menderita skabies adalah siswa pondok pesantren. 
Penyebabnya adalah tinggal bersama dengan sekelompok orang di pondok pesantren memang beresiko mudah tertular berbagai penyakit terutama penyakit kulit. Perilaku hidup bersih dan sehat terutama kebersihan perseorangan umumnya kurang mendapatkan perhatian dari para santri. Tinggal bersama dengan sekelompok orang seperti di pesantren memang berisiko mudah tertular berbagai penyakit kulit, khusunya penyakit skabies. Penularan terjadi bila kebersihan pribadi dan lingkungan tidak terjaga dengan baik. Masih ada pesantren yang tumbuh dalam lingkungan yang kumuh, tempat mandi dan wc yang kotor, lingkungan yang lembab, dan sanitasi yang buruk. Ditambah lagi dengan perilaku tidak sehat, seperti menggantung pakaian dalam kamar, tidak membolehkan santri wanita menjemur pakaian dibawah terik matahari, dan saling bertukar benda pribadi, seperti sisir dan handuk.

Berdasarkan survey awal pada tanggal 9 Februari 2012, peneliti mendapatkan informasi dari Puskesmas Air Dingin bahwa beberapa santri Pondok Pesantren Darul Ulum menderita skabies. Peneliti juga mendapat informasi dari pengelola pondok pesantren bahwa sebelumnya tidak pernah dilakukan penelitian kesehatan di Pondok Pendidikan Islam Darul Ulum dan hampir sebagian siswa mengeluhkan adanya penyakit pada kulit dengan keluhan gatal-gatal. Pondok Pendidikan Islam Darul Ulum terdiri dari 138 orang santri. Hal inilah yang mendorong penulis melakukan penelitian mengenai hubungan personal hygiene dengan kejadian skabies di Pondok Pendidikan Darul Ulum Palarik, Air Pacah.

Penelitian ini dilakukan bertujuan untuk mengetahui kejadian skabies siswa dan kebiasaan siswa dalam hal kebersihan diri.

\section{Metode}

Penelitian ini merupakan studi potong lintang (cross sectional) untuk mengetahui adanya hubungan personal hygiene dengan kejadian skabies di Pondok Pendidikan Islam darul Ulum Palarik Air pacah. Sampel penelitian yaitu semua santri di Pondok Pendidikan Islam darul Ulum Palarik Air pacah metode total sample. Kriteria inklusi sampel penelitian adalah santri yang bersedia menjadi sampel. Kriteria eksklusi adalah santri yang tidak hadir. Variabel dependen dari penelitian ini adalah Skabies. Sedangkan variabel independen adalah personal hygiene. Kedua variabel diukur menggunakan kuesioner dan observasi. Penelitian ini dilakukan di Pondok Pendidikan Islam darul Ulum Palarik Air Pacah, Kota Padang. Waktu penelitian sudah dilaksanakan bulan November tahun 2011 - Maret tahun 2013. Langkah-langkah pengolahan data adalah pemeriksaan kelengkapan dan kejelasan data, pemberian kode pada setiap data variabel, memasukkan data dalam program SPSS (Statistical Program for Social Science), serta pemeriksaan kembali untuk memastikan bahwa data tersebut telah bersih dari kesalahan. Analisis data terdiri dari analisis univariat dan bivariat. Pada analisis bivariat dicari hubungan antara dua variabel dengan menggunakan rumus chi square.
Hasil

Karakteristik responden

Tabel 1. Distribusi frekuensi jenis kelamin santri Pondok Pendidikan Islam Darul Ulum Palarik, Air Pacah

\begin{tabular}{cccc}
\hline No & $\begin{array}{c}\text { Jenis } \\
\text { kelamin }\end{array}$ & Frekuensi & $\%$ \\
\hline $\mathbf{1}$ & Laki-laki & 76 & 55,1 \\
$\mathbf{2}$ & Perempuan & 62 & 44,9 \\
& Jumlah & 138 & 100 \\
\hline
\end{tabular}

Berdasarkan tabel 1 diketahui sebagian besar santri di Pondok Pendidikan Islam Darul Ulum Palarik, Air Pacah berjenis kelamin laki-laki yaitu sebanyak 76 orang $(55,1 \%)$.

Tabel 2. Distribusi frekuensi umur santri Pondok Pendidikan Islam Darul Ulum Palarik, Air Pacah

\begin{tabular}{|c|c|c|c|}
\hline No & Umur & Frekwensi & $\%$ \\
\hline 1 & 10 & 1 & 0,7 \\
\hline 2 & 12 & 11 & 8 \\
\hline 3 & 13 & 37 & 26,8 \\
\hline 4 & 14 & 25 & 18,1 \\
\hline 5 & 15 & 19 & 13,8 \\
\hline 6 & 16 & 28 & 20,3 \\
\hline 7 & 17 & 7 & 5,1 \\
\hline 8 & 18 & 5 & 3,6 \\
\hline 9 & 19 & 3 & 2,2 \\
\hline 10 & 20 & 2 & 1,4 \\
\hline \multicolumn{2}{|c|}{ Jumlah } & 138 & 100 \\
\hline
\end{tabular}

Berdasarkan tabel 2 dapat diketahui santri Pondok Pendidikan Islam Darul Ulum Palarik, Air Pacah, paling banyak berumur 13 tahun yaitu sebanyak 37 orang $(26,8 \%)$.

Tabel 3. Distribusi frekuensi pendidikan santri Pondok Pendidikan Islam Darul Ulum Palarik, Air Pacah

\begin{tabular}{cccc}
\hline No & Pendidikan & Frekuensi & $\%$ \\
\hline $\mathbf{1 .}$ & Wustha & 110 & 79,7 \\
2. & MAS & 28 & 20,3 \\
\hline & Jumlah & 138 & 100 \\
\hline
\end{tabular}

Berdasarkan tabel 3 dapat diketahui santri Pondok Pendidikan Islam Darul Ulum Palarik, Air Pacah, paling banyak sedang menempuh pendidikan Wustha yaitu sebanyak 110 orang $(79,7 \%)$. 


\section{Hasil Analisis Univariat}

Tabel 4 Distribusi frekuensi kejadian skabies santri Pondok Pendidikan Islam Darul Ulum Palarik, Air Pacah

\begin{tabular}{cccc}
\hline No & $\begin{array}{l}\text { Kejadian } \\
\text { Skabies }\end{array}$ & Frekuensi & $\%$ \\
\hline $\mathbf{1}$ & Skabies & 34 & 24,6 \\
$\mathbf{2}$ & Tidak skabies & 104 & 75,4 \\
\hline & Jumlah & 138 & 100 \\
\hline
\end{tabular}

Berdasarkan tabel 4 diatas diketahui santri Pondok Pendidikan Islam Darul Ulum Palarik, Air Pacah, menderita penyakit skabies yaitu sebanyak 34 orang $(24,6 \%)$.

Tabel 5 Distribusi frekuensi personal hygiene santri Pondok Pendidikan Islam Darul Ulum Palarik, Air Pacah

\begin{tabular}{cccc}
\hline No & Personal Hygiene & Frekuensi & $\%$ \\
\hline $\mathbf{1}$ & Hygiene baik & 70 & 50,7 \\
$\mathbf{2}$ & Tidak Hygiene & 68 & 49,3 \\
\hline & Jumlah & 138 & 100 \\
\hline
\end{tabular}

Berdasarkan tabel 5 diatas diketahui sebagian besar santri Pondok Pendidikan Islam Darul Ulum Palarik, Air Pacah, mempunyai tingkat personal hygiene baik yaitu sebanyak 70 orang $(50,7 \%)$.

\section{Analisis Bivariat}

Tabel 6 Hubungan personal hygiene dengan kejadian skabies santri Pondok Pendidikan Islam Darul Ulum Palarik, Air Pacah

\begin{tabular}{|c|c|c|c|c|c|}
\hline & & Kejadian & Skabies & Total & $\begin{array}{l}P \\
\text { Value }\end{array}$ \\
\hline & & Skabies & $\begin{array}{c}\text { Tidak } \\
\text { skabies }\end{array}$ & & \\
\hline \multirow[t]{3}{*}{$\begin{array}{l}\text { Personal } \\
\text { hygiene }\end{array}$} & $\begin{array}{l}\text { Tidak } \\
\text { Hygiene }\end{array}$ & $30(44,1 \%)$ & $38(55,9 \%)$ & $68(100 \%)$ & \\
\hline & Hygiene & $4(5,7 \%)$ & $66(94,3 \%)$ & $70(100 \%)$ & 0,000 \\
\hline & Jumlah & $\begin{array}{c}34 \\
(24,6 \%) \\
\end{array}$ & $104(75,4 \%$ & $138(100 \%)$ & \\
\hline
\end{tabular}

Berdasarkan tabel 6 diketahui hasil analisis hubungan antara personal hygiene dengan kejadian skabies, didapatkan sebanyak 30 orang menderita skabies dengan personal hygiene yang tidak baik. Sedangkan 4 orang menderita skabies dengan personal hygiene yang baik. Hasil uji statistik diperoleh nilai $p<0,05$ yaitu 0,000 . Dapat disimpulkan ada hubungan yang bermakna dari kejadian skabies yang memiliki kriteria personal hygiene baik dan tidak baik.

\section{Pembahasan}

Berdasarkan hasil penelitian yang dilakukan menunjukkan bahwa sebagian besar santri yang menderita skabies adalah berjenis kelamin laki-laki. Insiden skabies laki-laki lebih banyak dari perempuan. ${ }^{9}$ Perempuan akan lebih kecil risiko terpapar penyakit skabies karena perempuan lebih cenderung merawat diri dan menjaga penampilan sedangkan laki-laki cenderung tidak memperhatikan penampilan diri dan akan berpengaruh terhadap perawatan kebersihan diri. ${ }^{10}$ Dapat disimpulkan bahwa hasil yang didapatkan sesuai dengan penelitian sebelumnya. Responden yang laki-laki akan lebih beresiko terserang skabies. Dengan perawatan diri yang bagus maka resiko terpaparnya skabies akan berkurang.

Berdasarkan hasil penelitian yang dilakukan menunjukkan bahwa responden berada pada kelompok umur antara 10-20 tahun. Dari kelompok umur tersebut, responden yang mengalami skabies dengan prevalensi terbanyak adalah berumur 13 tahun. Insiden skabies adalah responden yang berumur 12-13 tahun. $^{11}$ Beberapa penyakit menular tertentu menunjukkan bahwa umur muda mempunyai resiko yang tinggi. ${ }^{12}$ Dapat disimpulkan bahwa hasil yang didapatkan sesuai dengan teori dan penelitian sebelumnya. Responden yang berumur muda lebih beresiko terserang skabies. Tingkat kerentanan dan pengalaman terhadap penyakit tersebut biasanya sudah dialami oleh mereka yang berumur tinggi. ${ }^{12}$

Berdasarkan hasil penelitian yang dilakukan menunjukkan bahwa santri yang mengalami skabies sebagian besar berpendidikan kelas 1 Wustha. Tingkat pendidikan seseorang dapat meningkatkan pengetahuan itu termasuk pengetahuan tentang kesehatan. ${ }^{1}$ Dapat disimpulkan bahwa hasil yang didapatkan sesuai dengan teori sebelumnya. Responden dengan tingkat pendidikan lebih rendah lebih beresiko tertular penyakit skabies. Semakin tinggi pendidikan seseorang semakin banyak mendapatkan pelajaran bagaimana cara pencegahan penyakit yang menular.

Berdasarkan hasil penelitian yang dilakukan menunjukkan ada hubungan antara personal hygiene dengan kejadian skabies. Hygiene perorangan merupakan faktor risiko terjadinya penyakit skabies ${ }^{(13)}$. Hygiene perseorangan merupakan salah satu usaha yang dapat mencegah kejadian skabies. ${ }^{2,4}$ Dapat disimpulkan bahwa hasil penelitian sesuai dengan teori dan penelitian sebelumnya. Dari 34 orang yang menderita skabies didapatkan 30 orang dengan personal hygiene yang tidak baik. Personal hygiene yang tidak baik merupakan salah satu faktor yang bisa meningkatkan kejadian skabies.

\section{Kesimpulan}

Berdasarkan hasil penelitian yang telah dilakukan, maka peneliti dapat menarik kesimpulan bahwa terdapat hubungan antara personal hygiene dengan kejadian skabies di Pondok Pendidikan Islam Darul Ulum, Palarik Air Pacah. Didapatkan 34 orang dari 138 orang santri yang menjadi sampel mengalami skabies. Serta lebih dari setengah responden memiliki personal hygiene yang baik dan gambaran masing-masing personal hygiene santri baik.

\section{Daftar Pustaka}

1. Notoatmodjo, Soekidjo. 2003. Pendidikan dan Perilaku Kesehatan. Jakarta: Rineka Cipta.

2. Djuanda, Adhi. 2007. Ilmu Penyakit Kulit dan Kelamin. Jakarta:Fakultas Kedokteran Universitas Indonesia.

3. Chin, James. 2006. Manual Pemberantasan Penyakit Menular. Jakarta:Infomedika.

4. Harahap, Marwali. 2000. IImu Penyakit Kulit. Jakarta:Hipokrates

5. WHO, 2009. http://www.who.int/bulletin/volumes/87/2/07047308/en/edit 03 Juni 2012 pukul 00.06 WIB /Suci Chairiya Akmal 
6. Asra, Hajrin Pajri, 2010. Pengaruh Pengetahuan dan Tindakan Higinie Pribadi Terhadap Kejadian Penyakit Skabies di Pondok Pesantren Ar-Raudhatul hasanah Medan. Fakultas Kedokteran. Skripsi, Universitas Sumatera Utara, Medan.

7. Dinas Kesehatan Prop Sumbar. 2010. Profil Kesehatan Propinsi Sumatera Barat 2010

8. Dinas Kesehatan Kota Padang. 2010. Profil Kesehatan Kota Padang 2010

9. Andayani, Lita Sri. 2005. Perilaku Santri Dalam Upaya Pencegahan Penyakit Skabies di Pondok Pesantren Ulumu Qur'an stabat. Fakultas Kesehatan Masyarakat. Skripsi, Universitas Sumatera Utara, Medan.

10. Muin. 2009. Hubungan Umur, Pendidikan, Jenis Kelamin dan Kepadatan Hunian Ruang tidur Terhadap Kejadian Skabies. Fakultas Kesehatan Masyarakat. Skripsi, Universitas Muhammadiyah, Surakarta.
11. Frenki .2011. Hubungan Personal Hygiene Santri Dengan Kejadian Penyakit Kulit Infeksi Scabies dan Tinjauan Sanitasi Lingkungan Pondok Pesantren Darel Hikmah Kota Pekanbaru Tahun 2011. Fakultas Kesehatan Masyarakat. Skripsi, Universitas Sumatera Utara, Medan.

12. Noor, Nasry. 2008. Epidemiologi Penyakit Menular. Jakarta: PT Rineka Cipta.

13. Wijayanti, Yuni. 2008. Hubungan Sanitasi Lingkungan dan Hygiene Perorangan dengan Penyakit Skabies di Desa Genting Kec. Jambu Kab. Semarang tahun 2006. Jurnal KEMAS Vol. 3 No. 2. 